\title{
The Effects of Parent's Smartphone Dependency on Child's Smartphone Dependency: Serial Mediating Effects of Parenting, Child's Depression and Aggression
}

\author{
Sojin Yoon ${ }^{1}$, Myeongseong Lee ${ }^{1}$, Joonwoo Lee ${ }^{1}$, Sehee Hong ${ }^{2}$ \\ Ph.D. Student, Department of Educational Measurement and Statistics, Korea University, Seoul, Korea ${ }^{1}$ \\ Professor, Department of Educational Measurement and Statistics, Korea University, Seoul, Korea ${ }^{2}$ \\ 부모의 스마트폰 과의존이 아동의 스마트폰 과의존에 미치는 영향: \\ 부모의 양육태도와 아동의 우울 및 공격성의 순차적 매개효과 \\ 윤소진 ${ }^{1}$, 이명성 ${ }^{1}$, 이준우 ${ }^{1}$, 홍세희 $^{2}$ \\ 고려대학교 교육측정·통계학과 ${ }^{1}$, 고려대학교 교육측정·통계학과 교수 ${ }^{2}$
}

Objectives: This study examined the two-way effect of a parent's smartphone dependency on child's smartphone dependency focusing on the serial mediating effects of positive/negative parenting, and child's depression/aggression.

Methods: The sample comprised 2,290 fifth-grade elementary school students and their parents (father or mother). The results of descriptive statistics, Pearson correlation were calculated using SPSS 25 and the mediation model was analyzed using AMOS 25.0. The comparison among the serial mediation models was analyzed using AMOS 25.0 syntax.

Results: A parent's smartphone dependency had a significant direct effect on child's smartphone dependency. The mediating effects of both positive/negative parenting and child's depression/ agression on the relationship between parent's and child's smartphone dependency were significant, supporting the serial mediation model. As a parent's smartphone dependency increased, negative parenting increased while the positive parenting decreased. As negative parenting increased, a child's depression and aggression did as well, finally leading to higher levels of smartphone dependency in the child. In contrast, as positive parenting increased, the child's depression and aggression decreased leading to lower levels of smartphone dependency in the child. The path from parent's to child's smartphone dependency through negative parenting and aggression had the highest mediation effect. Conclusion: This study showed that the child's smartphone dependency is affected by not only by childrelated factors (depression and aggression) but also parent-related factors (smartphone dependency and parenting). Additionally, comparing mediational effects, interventions focusing on negative parenting and child's aggression might be more effective to reduce levels of child smartphone dependency.

Keywords: smartphone dependency, parenting, depression, aggression, Korean Children-Youth Panel Survey(KCYPS)

Corresponding Author: Sehee Hong, Professor, Department of Educational Measurement and Statistics, Korea University, 145, Anam-ro, Seongbukgu, Seoul, Korea

E-mail: seheehong@korea.ac.kr
(c)The Korean Association of Child Studies

This is an Open Access article distributed under the terms of the Creative Commons Attribution Non-Commercial License (http:// creativecommons.org/licenses/by-nc/4.0) which permits unrestricted noncommercial use, distribution, and reproduction in any medium, provided the original work is properly cited. 


\section{Introduction}

스마트폰은 학업, 업무, 여가 등 우리의 모든 생활 영역에서 주 요하게 사용되고 있으며, 우리나라의 스마트폰 보급률은 $95 \%$ 에 달한다(Taylor \& Silver, 2019). 아동과 청소년의 스마트폰 보 급률 또한 높은데, 2018년 기준 초등 고학년생의 스마트폰 보 급률은 81.2\%로(Taylor \& Silver, 2019) 이른 나이부터 스마트 폰이 매우 보편적으로 사용되고 있다. 스마트폰은 생활에 많 은 편리성을 가져다주었으나 그로 인한 부작용도 점차 대두되 고 있다. 특히 최근 코로나 19 로 인해 학생이 가정에서 학습하 고 생활하는 시간이 많아지면서 아동의 스마트폰 과의존이 사 회적 문제로 부상하였다.

스마트폰 과의존이란 과도한 스마트폰 이용으로 스마트폰 을 이용하는 생활패턴이 다른 행태보다 두드러지고 가장 중 요한 활동이 되며, 이용 조절력이 감소하여 문제적 결과를 경 험하는 상태를 말한다(Ministry of Science and ICT, 2020). 과의 존의 개념은 '인터넷 혹은 스마트폰 중독'에 대한 대체 개념으 로 정신병리적 접근에서 시작하였며, 스마트폰 이용을 억제하 기보다 균형적인 조절능력을 도와 궁극적으로 의미있고 생산 적인 디지털 이용문화를 조성하기 위한 목적으로 재개념화한 것이다(Aum, 2018). Ministry of Science and ICT (2020)에 따르 면 유.아동의 스마트폰 과의존 비율은 2018년 20.7\%, 2019년 $22.9 \%, 2020$ 년 27.3\%로 전 연령대에서 가장 가파르게 증가하 고 있으며, 특히 2020년에는 그 증가폭이 4.4\%로 심각한 수준 이다. 특히, 2018년을 기준으로 스마트폰 보급률이 초등학교 저학년 37.2\%, 초등학교 고학년 74.2\%, 중학생 $92.0 \%$, 고등학 생 93.5\%로 초등학교 저학년에서 고학년으로 올라갈 때 가장 크게 증가하는 것으로 나타났다(Y. H. Kim, 2019).

아동의 스마트폰 과의존은 아동의 삶의 다양한 측면에서 문제를 일으킨다. 아동의 스마트폰 과의존은 시각과 청각의 장애, 비만, 신체불균형, 두뇌발달에 영향을 미치며(C. Park \& Park, 2014), 좋지 않은 수면습관, 불안, 두통, 기억력 감소의 원 인이 된다(Anwar et al., 2021). 또한 아동의 스마트폰 과의존은 대인관계와 일상생활 적응에도 문제를 일으킨다. 일례로, 스 마트폰 과의존은 부모-자식간의 의사소통의 문제를 일으킬 뿐 아니라(H. S. Choi, Lee, \& Ha, 2012), 학교생활 적응 및 대 인관계에도 부정적인 영향을 미칠 수 있다(Y. M. Kim \& Kim, 2016). 학업수행에 있어서도 스마트폰 과의존은 책을 읽는 집 중도에 부적인 영향을 미치며, 학업성취에 직접적인 부적영향 을 미친다(Bukhori et al., 2019). 아동.청소년기는 신체적, 정서 적 성장이 가장 활발하게 진행되는 시기이므로, 스마트폰 과
의존으로 인한 이러한 부정적 결과는 그 심각성이 더 크다고 할 수 있다.

이러한 문제점을 해결하기 위해 아동의 스마트폰 과의존과 관련된 변인에 대한 연구가 많이 이루어졌는데, 그 중 부모 요 인은 매우 유력한 요인으로 알려져 있다(Nho \& Kim, 2016). 부모의 스마트폰 과의존은 자녀의 스트레스에 영향을 주며 (Shyan \& Arshat, 2019), 자녀의 사회적 능력에 부정적인 영향 을 주는 것으로 알려져 있다(Boo \& Park, 2018). 또한, 부모의 스마트폰 과의존은 그 자체로 아동의 스마트폰 과의존에 직접 적인 영향을 미치는 요인이자(Y. Cho \& Lee, 2016; Ha, 2020; Jeong \& Lee, 2020; N. R. Kim, Kim, \& Jeon, 2019; J. Park \& Hyun, 2018; H. G. Son, Cho, \& Jeong, 2021), 양육태도에 영향 을 미치는 요인이다(Chang, 2015b; D. H. Choi, 2019; J. Y. Lee \& Jang, 2014). 스마트폰 과의존인 부모들은 SNS와 채팅 앱 이 용에 많은 시간을 할애하여 아동의 양육에 집중하지 못하므 로(J. H. Kim \& Ahn, 2013), 부모의 스마트폰 과의존은 부모 의 양육태도에 부정적인 영향을 미친다(Chang, 2015b; D. H. Choi, 2019). 부모의 스마트폰 과의존은 가정의 소득, 어머니 의 연령, 스마트폰 사용시간을 통제하고도 양육태도에 영향을 미치는 것으로 나타났는데(Chang, 2015b), 구체적으로 어머니 의 스마트폰 의존 수준이 낮을수록 어머니의 온정, 격려 등 긍 정적 양육행동이 높았으며, 스마트폰 의존 수준이 높을수록 과보호, 허용, 거부, 방임 등 부정적 양육행동 수준이 높았다(J. Y. Lee \& Jang, 2014). 이러한 연구들을 살펴보았을 때, 부모의 스마트폰 과의존은 긍정적, 부정적 양육태도 모두에 영향을 미치는 주요 변인이라고 볼 수 있다.

부모의 양육태도는 부모의 스마트폰 과의존에 영향을 받음 과 동시에, 자녀의 스마트폰 과의존에 영향을 미칠 수 있다. 선 행연구에 따르면, 부모의 자율·수용.애정적 양육태도와 같은 긍정적 양육태도는 자녀의 스마트폰 과의존에 부적인 영향을 미치며(D. S. Moon \& Choi, 2015; Nho \& Kim, 2016), 부모의 부정적 양육태도는 자녀의 스마트폰 과의존에 정적인 영향을 미치는 것으로 나타났다(J. Choi \& Kwon, 2016; Ha, 2020; J. Y. Jeong \& Lee, 2020; Nho \& Kim, 2016). 이러한 선행연구는 부 모의 양육 태도가 부모의 스마트폰 과의존과 아동의 스마트폰 사이의 매개변인으로 기능할 가능성을 보여준다.

한편, 부모의 양육태도는 아동의 스마트폰 의존에 직접적 인 영향을 미치기도 하지만, 우울이나 공격성을 통해 간접적 인 영향을 미칠 수도 있다. 우울은 슬픔, 외로움, 무관심과 같 은 기분의 변화, 자기반복과 자기비난과 같은 부정적인 자아 개념, 도망가거나 숨거나 죽고 싶은 욕망, 거식증과 불면증 같 
은 신체적 변화, 지체하거나 동요하는 행동을 수반하는 상태 를 의미한다(Beck \& Alford, 2009). 우울은 자아존중감을 낮추 고, 자살을 더 생각하도록 하며(D. Y. Lee, Jung, \& Seo, 2017), 흡연, 사이버 비행과 같은 문제행동에 영향을 미친다(J. H. Kim, 2013; H. Park, Jang, Yoo, \& Koo, 2005).

부모의 양육태도와 자녀의 우울을 연구한 선행연구를 살 펴보면, 부모의 높은 감독, 사회적지지, 애정, 수용과 같은 긍 정적 양육태도는 우울을 감소시키며, 부모의 높은 학대, 심리 적 통제, 성취압력과 같은 부정적 양육태도는 우울을 증가시 키는 것으로 나타났다(Chang, 2015a; S. H. Cho \& Cho, 2021; I. Choi, 2012; Ku, 2013; Yim, Kim, \& Chung, 2014). 특히, 아동 을 대상으로 한 연구에서 부모의 비일관적 태도과 과잉간섭은 아동의 우울에 영향을 미치며(T. S. Choi \& Kim, 2015), 부모의 부정적 양육태도가 긍정적 양육태도보다 아동의 우울에 미치 는 영향이 강한 것으로 나타났다(Dallaire et al., 2006). 또한, 우 울은 스마트폰 의존을 예측하는 중요한 변인으로 알려져 있다 (S. Y. Kim \& Hong, 2014; Nho \& Kim, 2016; You, 2014). 아동 의 우울은 아동의 스마트폰 과의존에 영향을 미치는데(Chang et al., 2019; Joo, 2013), 아동이 우울 정도가 높은 경우 스마트 폰과 같은 매체에 집착하고 몰입하게 되면서 스마트폰 과의존 으로 이어질 수 있다.

우울과 함께 공격성 또한 스마트폰 과의존을 설명하는 주 요 변인으로 고려된다. 공격성은 일반적으로 타인을 의도 적으로 다치게 하거나 해하는 행동으로 정의된다(Crick \& Grotpeter, 1995). 부모의 양육태도와 공격성의 관계를 연구한 선행연구에 따르면, 긍정적 양육태도의 유형인 애착 양육태 도, 감독적 양육태도는 공격성의 감소와 관련이 있었고, 반대 로 부정적 양육태도인 무관심한 양육태도와 심리통제적 양 육태도는 공격성의 증가와 관련이 있었다(E. M. Park \& Park, 2014; S. Y. Kim, Kim, \& Lee, 2004). 특히, 선행 연구에서 아동 을 대상으로 한 연구에서 아버지의 강압적 양육태도와 어머니 의 허용.방임적 양육태도가 아동의 주도적인 공격성에 영향 을 미친다고 하였으며(Oh \& Kong, 2007), 긍정적인 양육태도 보다 부정적 양육태도가 아동의 공격성과 더 많은 관련이 있 는 것으로 나타났다(Chen \& Raine, 2018). 또한, 다수의 연구 에서 아동의 공격성향이 높을수록 스마트폰 과의존 수준이 높 은 것으로 나타났다(J. K. Kim \& Lee, 2018; H. J. Moon \& Shin, 2020; K. H. Park \& Park, 2020). 아동의 공격성은 관계 형성의 어려움에 영향을 미치고 그로 인해 아동은 스마트폰 사용에 더 몰두할 수 있다(Ryu \& Hong, 2014).

이러한 선행연구를 종합해보면, 아동의 스마트폰 과의존과
관련된 부모의 양육태도나 아동의 우울, 공격성의 관계를 밝 히려는 다양한 시도가 있었다는 것을 알 수 있다. 그러나 대다 수의 연구에서 변인들끼리의 한 가지, 또는 두 가지 경로에 대 해 다루었을 뿐 부모의 스마트폰 과의존, 아동의 스마트폰 과 의존, 그리고 부모의 양육태도 및 아동의 우울과 공격성의 구 조적 관계를 종합적으로 살펴본 연구는 부족하였다. 본 연구 와 유사하게 부모의 스마트폰 과의존이 부모의 부정적 양육태 도와 자녀 우울을 거쳐 자녀의 스마트폰 의존에 영향을 미치 는 순차적 매개효과를 확인한 연구가 존재하나(S. H. Cho \& Cho, 2021), 청소년을 연구대상으로 하여 스마트폰 보유율이 급증하는 초등학교 고학년 시기를 다루지 못한 한계점이 있었 다. 따라서 본 연구는 아동을 대상으로 부모의 스마트폰 과의 존이 아동의 스마트폰 과의존에 미치는 영향에서 부모의 양육 태도와 아동의 우울, 공격성의 매개효과를 살펴보고, 부모의 스마트폰 과의존에서 아동의 스마트폰 과의존으로 가는 경로 중 가장 큰 영향을 미치는 경로를 파악하고자 하였다. 이를 통 해 부모의 스마트폰 과의존, 양육태도 및 아동의 우울과 공격 성에 개입함으로써 아동의 스마트폰 과의존 문제를 체계적으 로 해결하는 방안에 대한 시사점을 도출하고자 하였다. 본 연 구의 연구문제는 아래와 같다.

\section{연구문제 1}

부모의 스마트폰 과의존, 아동의 스마트폰 과의존, 부모의 긍 정적, 부정적 양육태도, 아동의 우울, 공격성 간의 구조적 관 계는 어떠한가?

1-1. 부모의 스마트폰 과의존은 아동의 스마트폰 과의존에 직접적인 영향을 미치는가?

1-2. 부모의 스마트폰 과의존이 아동의 스마트폰 과의존에 미치는 영향이 부모의 긍정적, 부정적 양육태도와 아동의 우울 및 공격성에 의해 순차적으로 매개되는가?

1-3. 부모의 스마트폰 과의존이 아동의 스마트폰 과의존 에 미치는 영향에서 부모의 긍정적, 부정적 양육태도와 아 동의 우울 및 공격성의 순차적 매개효과 중 가장 큰 효과를 보이는 경로는 무엇인가? 


\section{Methods}

\section{연구대상}

본 연구는 한국아동청소년 패널조사 2018 (Korean Children and Youth Panel Survey [KCYPS])의 2차년도 자료를 이용하 였다. 패널은 아동과 아동의 보호자, 아동의 형제자매의 설 문조사 총 3 개의 개별 응답 데이터로 구성되어 있다(KCYPS, 2018). 본 연구에서는 아동과 아동의 보호자 데이터를 아동의 $\mathrm{ID}$ 를 기준으로 병합하여 사용하였다. KCYPS는 아동 1 명 당 보호자 1 명의 데이터가 짝지어져 있으며, 아동과 보호자 모두 조사원이 직접 가구에 방문하여 태블릿 $\mathrm{PC}$ 를 이용해 개별 대 면 면접으로 조사를 진행하였다.

본 연구는 전체 표본 중 부모가 아닌 사람이 보호자로 응답 한 경우와 스마트폰을 사용하지 않는다고 응답한 아동과 부모 의 케이스는 제외하여, 총 2,290 명의 아동과 이들의 보호자(부 또는 모) 2,290 명을 조사에 활용하였다. 초등학교 5학년 아동 은 남자 1,134 명, 여자 1,156 명이었고, 어머니는 2,102 명, 아버 지는 188 명이었다. 어머니의 학력은 고등학교 졸업이 $26.5 \%$, 2-3년제 대학 졸업이 $30.7 \%$, 4년제 대학 졸업이 $33.1 \%$ 대학 원 졸업이 $6.5 \%$ 였으며, 아버지의 학력은 고등학교 졸업이 $23.4 \%, 2-3$ 년제 대학 졸업이 $23.0 \%$, 4년제 대학 졸업이 $37.8 \%$ 대학원 졸업이 $10 \%$ 이었다. 전체 응답 아동 중 2,236명 $(95.9 \%)$ 이 스마트폰을 사용하고 있었으며, 부모 중 2,423명(99.5\%) 이 스마트폰을 사용하고 있었다. 아동의 평일 스마트폰 사용 시간은 30 분 2 시간 미만이 가장 많았고(52.5\%), 30 분 미만 이 $19.0 \%, 2$ 시간 이상 3 시간 미만이 $11.1 \%$ 로 뒤를 이었다. 주말 스마트폰 사용 시간 역시 30 분 2시간 미만이 가장 많 았고(40.2\%), 30 분 미만이 $18.1 \%, 2$ 시간 이상 3시간 미만이 $13.2 \%$ 로 뒤를 이었다.

\section{연구도구}

\section{부모 및 아동의 스마트폰 과의존}

부모의 스마트폰 과의존은 Kim 등 (2012)이 개발한 스마트폰 과의존 자가진단 척도를 활용하여 측정되었다. 본 연구에서는 아동의 스마트폰 과의존 수준과 각 아동 당 1 명의 보호자(아 버지 또는 어머니)의 스마트폰 과의존 수준을 분석에 활용하 였다. 척도는 총 15 개의 문항으로 구성되어 있으며, 모든 문항 은 Likert 4점 척도로 측정되었다. 15문항 중 3문항(“스마트폰
사용이 지금하고 있는 일(공부)에 방해가 되지 않는다.” "스마 트폰이 없어도 불안하지 않다", “스마트폰 사용에 많은 시간 을 보내지 않는다.”)은 역채점하였다. 점수가 높을수록 스마 트폰 과의존 정도가 높은 것으로 해석한다. 부모와 아동의 스 마트폰 과의존은 동일한 문항으로 측정되었다. 본 연구에서 부모의 스마트폰 과의존 문항에 대한 신뢰도(Cronbach's $\alpha$ )는 .861로 나타났으며, 아동의 스마트폰 과의존 문항에 대한 신 뢰도(Cronbach's $\alpha$ )는 .875로 나타났다.

\section{긍정적 및 부정적 양육태도}

양육태도는 한국판 청소년용 동기모형 부모양육태도척도를 사용하여 측정되었다(K. I. Kim \& Lee, 2017). 부모양육태도척 도는 아동이 지각한 부모의 긍정적 양육태도(애정, 자율성지 지, 구조제공)와 부정적 양육태도(거부, 강요, 비일관성)를 측 정한다. 문항은 긍정적 양육태도 12 개, 부정적 양육태도 12 개 로 구성되어 있으며, Likert 4점 척도로 측정되었다. 점수가 높 을수록 긍정적 또는 부정적 양육태도를 많이 보이는 것으로 해석한다. 긍정적 양육태도 문항은 "부모님이 나를 사랑한다 는 것을 표현하신다.” 등이 있으며, 부정적 양육태도 문항은 "부모님은 사전에 주의도 주지 않고 화부터 내신다" 등이 있 다. 본 연구에서 긍정적 양육 문항에 대한 신뢰도(Cronbach's $\alpha)$ 는 .909으로 나타났으며, 부정적 양육 문항에 대한 신뢰도 (Cronbach's $\alpha$ )는 .858로 나타났다.

\section{아동의 우울}

아동의 우울은 간이 정신진단검사(K. I. Kim, Kim, \& Won, 1984)를 KYCPS 2018에서 선별한 문항을 사용하였다. 문항은 총 10 개로, "불행하다고 생각하거나 슬퍼하고 우울해한다", "모든 일에 관심과 흥미가 없다", "외롭다" 등으로 구성되어 있으며, Likert 4점 척도로 측정되었다. 아동이 직접 자신의 우 울을 평가하며, 점수가 높을수록 우울감이 높은 것으로 해석 한다. 본 연구에서 전체 문항에 대한 신뢰도(Cronbach's $\alpha$ )는 .904이었다.

\section{아동의 공격성}

아동의 공격성은 아동의 정서.행동문제 자기보고형 평정척도 (Jo \& Im, 2003)를 KCYPS에서 일부를 제외 및 수정한 문항을 사용하였다. 문항은 총 6 개로, "별 것 아닌 일로 싸우곤 한다", 
"하루 종일 화가 날 때가 있다" 등으로 구성되어 있으며, Likert 4점 척도로 측정되었다. 아동이 직접 자신의 공격성을 평가하 며, 점수가 높을수록 공격성이 높은 것으로 해석한다. 본 연구 에서 전체 문항에 대한 신뢰도(Cronbach's $\alpha$ )는 .834였다.

\section{자료분석}

본 연구는 부모의 스마트폰 과의존이 아동의 스마트폰 과의 존에 미치는 영향에서 긍정적, 부정적 양육태도와 아동의 우 울, 공격성의 매개효과 검증을 위해 구조방정식 모형을 활용 하였다. 이 때 성별에 따라 스마트폰 과의존 및 심리적 특성 이 다르며(Kang, \& Shin, 2014; H. N. Lee \& Yang, 2018), 양육 이 스마트폰 과의존에 미치는 영향이 다르다는 선행 연구(H. N. Lee \& Yang, 2018)를 참고하여 성별을 통제변수로 설정하 였다. 각 구인에 해당하는 문항들은 항목묶음(item parceling) 방법을 이용하여 지표변수(indicator)로 활용되었다. 이를 통 해 자료의 비정규성을 줄이고, 간명성을 높여 모형의 적합도 를 상승시키고자 하였다(Bandalos, 2002; Russell, Kahn, Spoth, \& Altmaier, 1998). 본 연구는 각 지표변수에 잠재변수의 특성 이 골고루 반영되어 지표변수 간 특성이 유사하도록 항목묶 음을 구성하였다. 검사 중 하위요인이 존재하는 문항의 경우, 각 지표변수가 개념을 대표할 수 있도록 각 요인에 속하는 문
항을 골고루 선택하여 합산하는 방식인 개념영역 대표성 방법 (domain representative approach)을 사용하였다(Hong \& Jung, 2014; Little, Cunningham, Shahar, \& Widaman, 2002). 그 결과 부모와 자녀의 스마트폰 과의존, 긍정적 양육 및 부정적 양육 의 지표변수는 각 4 개로 구성되었다. 단일차원인 경우 각 문 항합산 결과의 요인계수의 크기가 동일하도록 하는 균형할당 방법(balancing assignment) 방법을 사용하였다(Hong \& Jung, 2014; Little et al., 2002). 그 결과 아동의 우울은 4개, 공격성은 3 개의 지표변수로 구성되었다.

부모의 스마트폰 과의존과 아동의 스마트폰 과의존이 같 은 문항으로 측정되었기 때문에 두 집단에서 스마트폰 과의존 잠재변수가 동일한 개념을 측정하는지를 측정동일성 모형 검 증을 통해 확인하였다(Collier, 2020). 또한 부모와 아동의 스마 트폰 과의존이 같은 문항으로 측정되었기 때문에, 각 지표변 수에서 잠재변수로 설명되고 남은 오차들 역시 서로 유사한 특성을 지닐 가능성이 존재한다. 즉, 같은 문항으로 측정된 부 모와 아동의 스마트폰 과의존의 지표변수의 각 오차 쌍은 서 로 독립적이지 않으며 체계적인 분산이 존재한다. 따라서 본 연구에서는 부모와 아동의 스마트폰 과의존의 각 지표변수의 측정오차에 공분산을 설정하여 구조모형 분석을 진행하였다 (Cook \& Kenny, 2005; Kenny, Kashy, \& Cook, 2006). 모형의 적 합도는 $\chi^{2}(d f), \mathrm{TLI}, \mathrm{CFI}$, 및 RMSEA값을 종합적으로 검토하였

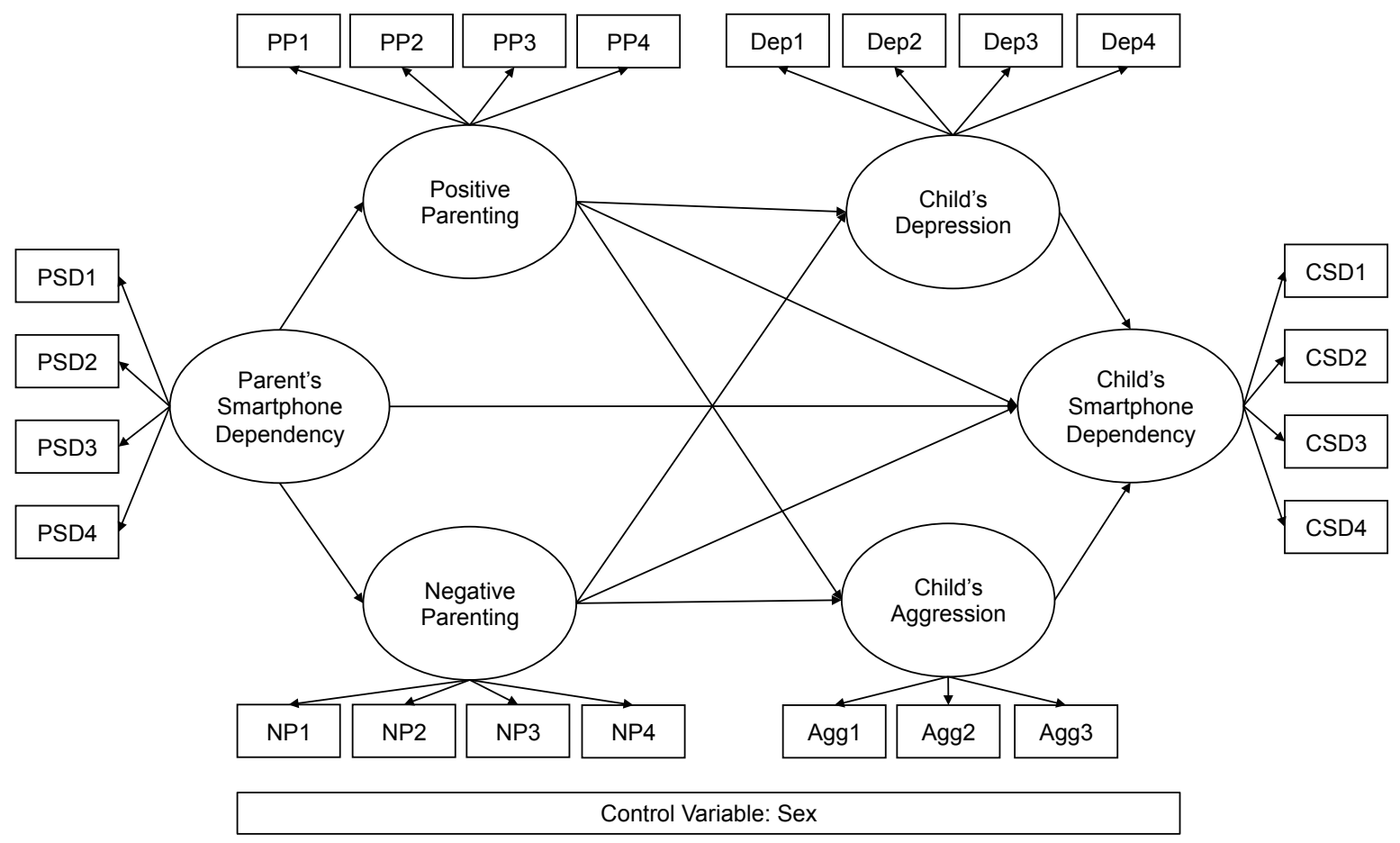

Figure 1. The hypothesized model. 
다. CFI와 TLI는 . 90 이상인 경우 좋은 적합도, RMSEA는 .05 이 하이면 좋은 적합도, .08 이하이면 합당한 모형으로 알려져 있 다(Hong, 2000). 매개효과는 부트스트래핑(bootstrapping) 방법 (Shrout \& Bolger, 2002)을 이용하여 검증하였으며, 유한한 표 본으로 인한 bias를 교정한 결과인 bias-corrected $95 \% \mathrm{CI}$ 를 통 해 매개효과의 유의성을 판단하였다. 본 연구에서 주요 변수들 의 기술통계 및 상관분석은 SPSS 25.0 (IBM Co., Armonk, NY) 을 사용하였고, 측정 동일성 검정, 매개효과 분석은 AMOS 22 (IBM Co., Armonk, NY)를, 매개효과 비교 분석은 AMOS syntax 를 사용하였다. 최종 모형은 Figure 1과 같다.

\section{Results}

\section{기술통계 및 상관분석}

본 연구의 주요 변인인 부모의 스마트폰 과의존, 부모의 긍정 적, 부정적 양육태도, 아동의 우울 및 공격성, 아동의 스마트 폰 과의존, 통제변수인 성별의 기술통계 및 상관분석 결과를 Table 1에 제시하였다. 본 연구의 모든 변인의 왜도는 -0.660.92 사이, 첨도는 -0.39-0.81 사이로, 자료는 정상성 가정에 크 게 위배되지 않았다(Curran, West, \& Finch, 1996). 부모의 스마 트폰 과의존과 부정적 양육태도 $(r=.27, p<.01)$, 아동의 우울 $(r=.23, p<.01)$, 아동의 공격성 $(r=.25, p<.01)$, 아동의 스마트 폰 과의존 $(r=.30, p<.01)$ 은 유의미한 정적 상관을 보였고, 긍 정적 양육태도는 부적 상관을 보였다 $(r=-.22, p<.01)$. 긍정적 양육태도는 아동의 우울 $(r=-.44, p<.01)$, 공격성 $(r=-.36, p<$ $.01)$, 아동의 스마트폰 과의존 $(r=-.34, p<.01)$ 과 모두 유의미 한 부적인 상관을 보였으며, 부정적 양육태도는 모두 유의미 한 정적 상관을 보였다 $(r=.38-.50, p<.01)$. 아동의 우울과 공 격성은 높은 정적 상관을 보였고 $(r=.65, p<.01)$, 아동의 성별 은 부모의 스마트폰 과의존 $(r=.07, p<.01)$ 과 아동의 우울 $(r=$ $.08, p<.01)$ 에 정적인 상관을 보였다.

\section{부모 및 아동의 스마트폰 과의존 측정동일성 검증}

부모의 스마트폰 과의존과 아동의 스마트폰 과의존이 같은 문 항으로 측정되었기 때문에 두 집단에서 스마트폰 과의존 잠재 변수가 동일한 개념을 측정하는지에 대한 확인이 필요하다. 이 를 위해 측정모형의 전체적 형태가 집단별로 동일한지 살펴보 는 기저모형(형태동일성 모형) 검증을 실시하였고, 다음으로
집단별 요인부하량을 동일하게 제약하여 스마트폰 과의존 잠 재변수의 의미가 두 집단에서 동일한지 확인하는 측정동일성 을 검증을 실시하였다(Collier, 2020). 각 절차 간 모형의 비교 는 내재된 모형이므로 카이제곱 차이검증이 가능하나, 카이제 곱 검증은 표본크기가 클수록 영가설을 쉽게 기각하는 경향이 있어 TLI, CFI, RMSEA 지수를 비교하였다. 기저모형 검증 결 과 $\chi^{2}(4)=148.253, \mathrm{TLI}=.957, \mathrm{CFI}=.986, \mathrm{RMSEA}=.089$ 으로 나타났다. RMSEA가 상대적으로 높으나 일반적으로 RMSEA 는 .08-1일 때 수용가능한 수준인 것으로 간주된다(Browne \& Cudeck, 1992). 이에 다른 적합도 지수들을 함께 고려하여 기 저모형의 적합도가 양호하다고 판단하였다(Table 2). 다음으로 완전 측정동일성을 전제로 기저모형과 측정동일성 모형의 차 이를 검증한 결과 $\chi^{2}(3)=9.749, p=.021$ 로 집단 간 차이가 유의 하게 나타났다. 그러나 TLI와 RMSEA의 경우 완전 측정동일성 모형의 적합도가 더 우수하였고 $(\triangle \mathrm{TLI}=.017, \triangle \mathrm{RMSEA}=.02)$, $\triangle \mathrm{CFI}$ 는 .001이내로 그 차이가 유의하게 크지 않았다(Chen, 2007; Hong, Malik, \& Lee, 2003). 따라서 부모의 스마트폰 과 의존과 아동의 스마트폰 과의존에서 완전 측정동일성이 성립 한다고 보았다. 또한 두 집단에서 측정된 스마트폰 과의존 잠 재변수가 동일한 의미를 지닌다고 가정하였을 때, 잠재변수를 구성하고 있는 각 지표변수의 측정오차 역시 독립적이지 않으 며 체계적인 분산이 존재하므로 부모와 아동의 스마트폰 과의 존의 각 지표변수 쌍의 오차에 공분산을 설정하였다(Cook \& Kenny, 2005; Kenny, Kashy, \& Cook, 2006).

\section{부모의 스마트폰 과의존이 양육태도 및 아동의 부적정서를 매개로 아동의 스마트폰에 미치는 영향}

구조모형 모델 적합도는 전반적으로 양호한 수준이었다 $\left(\chi^{2}(235)=2067.063, \mathrm{TLI}=.939, \mathrm{CFI}=.948, \mathrm{RMSEA}=.058\right)$. 아 동의 성별을 통제한 연구모형의 변수 간 관계 결과는 Table 3 과 같이 나타났다. 부모의 스마트폰 과의존은 긍정적 양육태도 에는 부적인 영향을 $(\beta=-.259, p<.01)$, 부정적 양육태도에는 정적인 영향을 유의하게 미치는 것으로 나타났다 $(\beta=.335, p$ <.01). 또한 부모의 스마트폰 과의존은 아동의 스마트폰 과의 존에 직접적인 정적 영향을 미치는 것으로 나타났다 $(\beta=.188$, $p$ <.01). 즉, 부모의 스마트폰 과의존이 높을수록 긍정적 양육 태도는 낮고, 부정적 양육태도는 높으며, 아동의 스마트폰 과 의존도 높았다. 긍정적 양육태도는 아동의 우울 $(\beta=-.297, p<$ $.01)$, 공격성 $(\beta=-.202, p<.01)$ 에 부적 영향을 미침과 동시에 아동의 스마트폰 과의존 $(\beta=-.123, p<.01)$ 에도 직접적인 부 
Table 1

Descriptive Statistics and Correlations of Major Variables

\begin{tabular}{|c|c|c|c|c|c|c|c|}
\hline & 1 & 2 & 3 & 4 & 5 & 6 & 7 \\
\hline 1. Parent's smartphone dependancy & - & & & & & & \\
\hline 2. Positive parenting & $-.22^{* *}$ & - & & & & & \\
\hline 3. Negative parenting & $.27^{* *}$ & $-.46^{* *}$ & - & & & & \\
\hline 4. Depression & $.23^{* *}$ & $-.44^{* *}$ & $.50^{* *}$ & - & & & \\
\hline 6. Child's smartphone dependancy & $.30^{* *}$ & $-.34^{* *}$ & $.38^{* *}$ & $.38^{* *}$ & $.43^{* *}$ & - & \\
\hline 7. Sex of child & $.07^{* *}$ & .01 & -.02 & $.08^{* *}$ & -.01 & -.04 & - \\
\hline$M$ & 1.89 & 3.32 & 1.99 & 1.65 & 1.83 & 1.97 & 1.50 \\
\hline
\end{tabular}

Note. $N=2,290$.

${ }^{* *} p<.01$.

Table 2

Result of Metric Invariance Test

\begin{tabular}{lccccc}
\hline \multicolumn{1}{c}{ Model } & $\chi^{2}(d f)$ & $\Delta \chi^{2}$ & TLI & CFI & RMSEA \\
\hline Baseline (configural invariance model) & $148.253(4)$ & & .957 & .986 & .089 \\
Full metric invariance model & $158.002(7)$ & $9.749(3)$ & .974 & .985 & .069 \\
\hline
\end{tabular}

Note. $N=2,290$.

Table 3

Regression Coefficient of Each Path

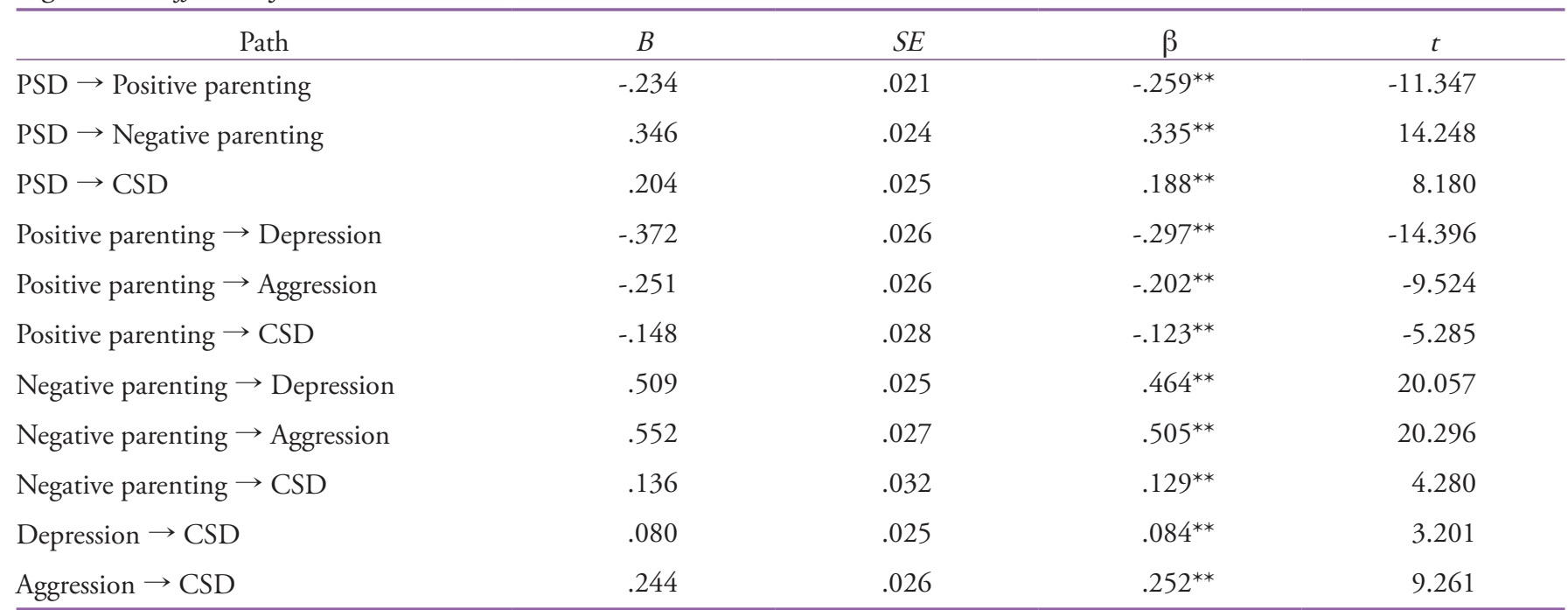

Note. $N=2,290$. PSD = Parent's Smartphone Dependency, CSD = Child's Smartphone Dependency.

${ }^{* *} p<.01$. 


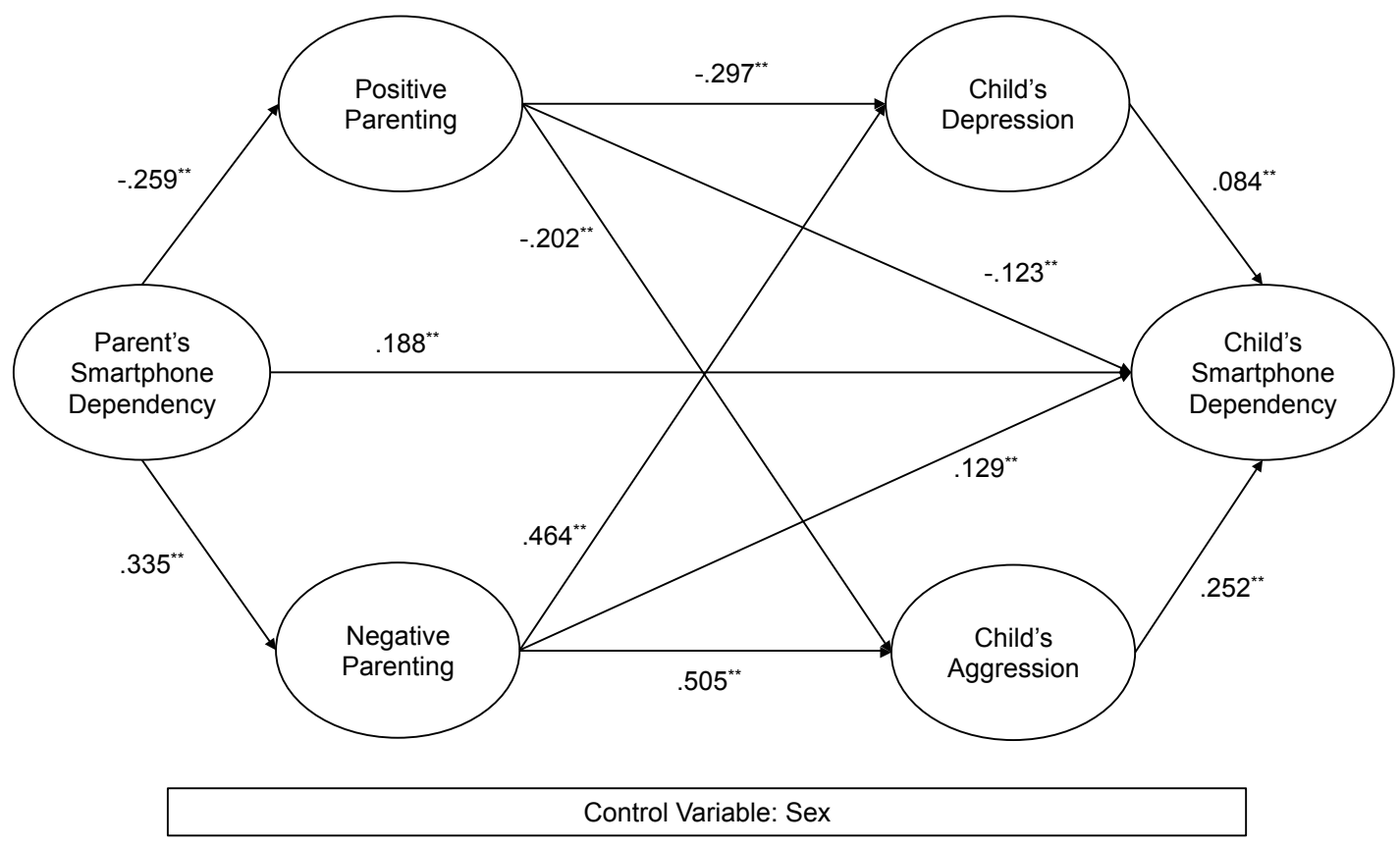

Figure 2. Serial mediation effects of parenting and negative affect.

${ }^{* *} p<.01$.

Table 4

Results of Serial Mediating Effects Using Bias-corrected Bootstrapping

\begin{tabular}{|c|c|c|c|c|}
\hline \multirow[t]{2}{*}{ Path } & \multirow[t]{2}{*}{ Estimate } & \multirow[t]{2}{*}{$S E$} & \multicolumn{2}{|c|}{$\begin{array}{c}\text { bias-corrected } \\
95 \% \mathrm{CI}\end{array}$} \\
\hline & & & Lower & Upper \\
\hline PSD $\rightarrow$ Negative parenting $\rightarrow$ Depression $\rightarrow$ CSD & $.014^{*}$ & .006 & .003 & .026 \\
\hline PSD $\rightarrow$ Positive parenting $\rightarrow$ Aggression $\rightarrow$ CSD & $.014^{* *}$ & .003 & .009 & .022 \\
\hline
\end{tabular}

Note. $N=2,290$. PSD = Parent's Smartphone Dependency, CSD = Child's Smartphone Dependency.

${ }^{*} p<.05 .{ }^{* *} p<.01$.

적 영향을 미치는 것으로 나타났다. 즉, 부모가 긍정적 양육을 행할수록 아동의 우울과 공격성은 낮아지며, 아동의 스마트 폰 과의존도 낮아진다. 부정적 양육태도 역시 아동의 우울 $(\beta=$ $.464, p<.01)$ 및 공격성 $(\beta=.505, p<.01)$ 에 유의한 정적 영향 을 미치면서 아동의 스마트폰 과의존 $(\beta=.129, p<.01)$ 에 직접 적인 정적 영향을 미치는 것으로 나타났다. 즉, 부모가 부정적 양육을 행할수록 아동의 우울과 공격성이 높아지며, 아동의 스마트폰 과의존도 높아진다. 아동의 우울과 $(\beta=.084, p<.01)$ 공격성 $(\beta=.252, p<.01)$ 은 아동의 스마트폰 과의존에 유의하 게 정적인 영향을 미치는 것으로 나타났다(Figure 2).

다음으로 부모의 스마트폰 과의존과 아동의 스마트폰 과의 존의 관계에서 부모의 긍정적, 부정적 양육태도와 아동의 우
울, 공격성의 순차 매개효과를 살펴보았다. 부모의 스마트폰 과의존과 아동의 스마트폰 과의존 사이에서 긍정적 양육태도 와 아동의 우울의 순차 매개효과 $(B=.007,95 \% \mathrm{CI}[.002, .013])$, 부정적 양육태도와 아동의 우울의 순차 매개효과 $(\mathrm{B}=.014$, $95 \% \mathrm{CI}[.003, .026])$ 가 유의하였다. 또한 부모의 스마트폰 과 의존과 아동의 스마트폰 과의존 사이에서 긍정적 양육태도와 아동의 공격성의 순차 매개효과 $(B=.014,95 \% \mathrm{CI}[.009, .022])$, 부정적 양육태도와 아동의 공격성의 순차 매개효과 $(B=.046$, $95 \% \mathrm{CI}[.032, .063)$ 도 통계적으로 유의하였다. 이는 부모의 스 마트폰 과의존이 긍정적, 부정적 양육태도와 아동의 우울 및 공격성을 통해 아동의 스마트폰 과의존에 영향을 미침을 보여 준다(Table 4). 
Table 5

Comparing Serial Mediation Effects

\begin{tabular}{|c|c|c|c|c|}
\hline \multirow[b]{2}{*}{ Path } & \multirow[b]{2}{*}{ Estimate } & \multirow[b]{2}{*}{$S E$} & \multicolumn{2}{|c|}{$\begin{array}{c}\text { bias-corrected } \\
95 \% \mathrm{CI}\end{array}$} \\
\hline & & & Lower & Upper \\
\hline PSD $\rightarrow$ Positive parenting $\rightarrow$ Depression $\rightarrow$ CSD vs PSD $\rightarrow$ Positive parenting $\rightarrow$ Aggression $\rightarrow$ CSD & -.007 & .005 & -.018 & .001 \\
\hline PSD $\rightarrow$ Negative parenting $\rightarrow$ Depression $\rightarrow$ CSD vs PSD $\rightarrow$ Negative parenting $\rightarrow$ Aggression $\rightarrow$ CSD & $-.032^{* *}$ & .011 & -.055 & -.012 \\
\hline PSD $\rightarrow$ Positive parenting $\rightarrow$ Depression $\rightarrow$ CSD vs PSD $\rightarrow$ Negative parenting $\rightarrow$ Depression $\rightarrow$ CSD & $-.007^{* *}$ & .004 & -.016 & -.002 \\
\hline PSD $\rightarrow$ Positive parenting $\rightarrow$ Aggression $\rightarrow$ CSD vs PSD $\rightarrow$ Negative parenting $\rightarrow$ Aggression $\rightarrow$ CSD & $-.032^{* *}$ & .007 & -.048 & -.020 \\
\hline
\end{tabular}

Note. $N=2,290$. PSD = Parent's Smartphone Dependency, CSD = Child's Smartphone Dependency. ${ }^{* *} p<.01$.

마지막으로 각 순차매개 효과를 비교하기 위해 매개효과 의 차이 검증을 실시하여 Table 5에 제시하였다. 앞서 각 순차 매개 경로의 긍정적 양육 경로에서 아동의 우울보다 공격성 의 효과가 더 큰 것으로 보였으나, 매개효과 차이검증 결과 통 계적으로 그 차이는 유의하지 않았다 $(B=-.007,95 \% \mathrm{CI}[-.018$, .001]). 반면 부정적 양육 경로에서 아동의 우울과 공격성의 차 이는 유의하였는데 $(B=-.032,95 \% \mathrm{CI}[-.055,-.012])$, 이는 부정 적 양육을 통해 우울 또는 공격성으로 이어지는 경로에서 아 동의 우울보다 공격성의 효과가 더 큰 것으로 해석할 수 있다. 다음으로 긍정적 양육과 부정적 양육의 차이를 확인하기 위해 부모의 스마트폰 과의존이 부모의 양육, 아동의 우울을 거쳐 아동의 스마트폰 과의존으로 가는 경로에서 긍정적 양육과 부 정적 양육의 차이를 비교하였다. 그 결과, 긍정적 양육과 부정 적 양육의 차이는 통계적으로 유의하였다 $(B=-.007,95 \% \mathrm{CI}[-$ $.016,-.002]$. 즉, 아동의 우울로 가는 경로에서 긍정적 양육보 다 부정적 양육의 효과가 유의하게 더 큰 것으로 나타났다. 또 한 아동의 공격성을 통해 아동의 스마트폰 과의존으로 가는 경로에서도 긍적적 양육태도와 부정적 양육태도의 차이가 유 의하였다 $(B=-.032,95 \% \mathrm{CI}[-.048,-.020])$. 이는 아동의 공격성 으로 가는 경로에서도 긍정적 양육보다 부정적 양육의 효과가 더 큰 영향력을 미침을 보여준다.

\section{Discussion}

본 연구는 한국 아동.청소년 패널조사 2018의 2 차년도 자료를 이용하여 부모의 스마트폰 과의존이 아동의 스마트폰 과의존 에 미치는 영향에서 부모의 긍정적, 부정적 양육태도, 아동의 우울과 공격성의 순차적 매개효과를 검증하였다. 구조모형의 경로계수 및 매개효과를 분석한 결과를 정리하면 다음과 같다.
첫째, 부모의 스마트폰 과의존이 아동의 스마트폰 과의 존에 미치는 직접효과가 유의하였다. 이는 부모의 스마트폰 과의존이 아동에게 영향을 준다는 기존의 연구들 $(\mathrm{Ha}, 2020$; Jeong \& Lee, 2020; N. R. Kim, Kim, \& Jeon, 2019)과 일치하는 결과이다. 아동은 가정에서 부모와 대화나 정서적 교감을 많 이 할 때 심리적 안정을 얻을 수 있다. 하지만 부모가 스마트폰 과의존일 경우 적절한 양육을 받지 못한 아동은 부모와의 대 화를 하지 못하는 데서 오는 심리적 결손을 스마트폰을 통해 해소하려는 것으로 보인다. 따라서 아동이 스마트폰 과의존을 보이는 경우 부모는 아동에게 그 책임을 전가하기보다 자신이 스마트폰에 과의존하고 있지 않은지 점검할 필요가 있다. 더 불어 아동과 함께 스마트폰 과의존을 줄이기 위한 가족 공동 체로써의 노력을 기울일 필요가 있다.

둘째, 부모의 스마트폰 과의존이 부모의 양육태도, 아동의 우울 및 공격성을 순차적으로 매개하여 아동의 스마트폰 과의 존에 영향을 미치는 순차 매개효과가 유의하게 나타났다. 경 로를 구체적으로 살펴보면, 부모의 스마트폰 과의존은 긍정적 양육태도에 부적 영향을 주며, 부정적 양육태도에는 정적 영 향을 주는 것으로 나타났다. 이는 부모가 스마트폰에 의존하 게 되면 가정에서 부모로서의 역할이 감소되고, 양육의 질이 감소된다는 선행 연구(J. Park \& Hyun, 2018)와 부합한다. 이 는 부모가 스마트폰에 의존하고 중독되면 아동에게 쏟을 수 있는 에너지와 관심을 빼앗겨 양육에 온전히 힘을 기울이지 못하는 결과로 볼 수 있다. 이어서 양육태도에서 우울, 공격성 으로의 경로를 살펴보면, 긍정적 양육태도는 아동의 우울, 공 격성에 부적 영향을 주며, 부정적 양육태도는 아동의 우울, 공 격성에 정적 영향을 주는 것으로 나타났다. 이는 부모의 양육 태도와 아동의 우울 및 공격성의 관계를 밝혔던 선행연구들 (Kawabata et al., 2011; Ku, 2013; Lim, 2017)에 의해서도 지지 된다. 부모의 온정적이고 격려하는 양육태도는 아동이 부정적 
경험을 하더라도 그 것을 해결할 수 있는 심리적 자원이 되어 우울, 공격성을 줄일 수 있는 것으로 보인다. 반면, 강압적이고 비판적인 양육태도는 아동을 심리적으로 고립하게 하여 우울, 공격성을 일으킬 수 있다. 다음으로 아동의 우울, 공격성은 스 마트폰 과의존에 정적 영향을 미치는 것으로 나타났는데, 이 는 우울이 스마트폰 과의존의 예측 변인이라는 연구들(S. Y.

Kim \& Hong, 2014; Nho \& Kim, 2016; You, 2014)과 공격성과 스마트폰 과의존의 관계를 밝힌 여러 연구들(J. K. Kim \& Lee, 2018; H. J. Moon \& Shin, 2020; K. H. Park \& Park, 2020)에 의 해서도 지지된다. 아동은 불안하고 결핍된 감정을 중독 대상 을 통해 보상 받으려는 경향이 있는데(Flores, 2004), 손쉽게 접 할 수 있으며 즉각적인 만족을 주는 스마트폰에 의존함으로써 우울과 공격성을 보상 받으려는 것으로 보인다.

지금까지의 순차 매개효과를 종합하면, 부모가 스마트폰에 의존하지 않을 때 자녀 양육에 집중할 수 있고, 애정적, 지지적 인 양육을 받은 아동은 정서가 안정되어 스마트폰 사용 동기 가 낮아진다는 결론을 얻을 수 있다. 반대로 부모의 스마트폰 과의존 수준이 높으면 결국 온전히 양육에 힘을 기울이지 못 하며, 이는 아동에게 고립감을 일으켜 우울, 공격성 등의 정서. 행동 문제를 일으키고, 아동은 이러한 문제를 해소하기 위해 스마트폰에 과도하게 의존하게 된다고 해석할 수 있다. 이렇 듯 부모의 스마트폰 과의존과 아동의 스마트폰 과의존의 관계 에 양육태도, 아동의 우울 및 공격성이 순차적으로 매개하고 있다는 점은 부모의 요소(스마트폰 과의존, 양육태도)와 아동 의 요소(우울 및 공격성) 모두에 대한 개입을 통해 아동의 스 마트폰 과의존을 해결해야 한다는 시사점도 주고 있다.

셋째, 매개 효과의 경로를 비교 검증한 결과 부정적 양육태 도가 포함된 경로의 매개효과가 긍정적 양육태도가 포함된 것 보다 유의하게 높게 나타났다. 부정적 양육태도의 경우 아동 의 정서.행동 문제를 일으키는 직접적인 원인이 되므로 아동에 게 더욱 큰 영향을 주는 것으로 보인다. 따라서 부모가 행동을 개선할 때 긍정적 양육태도를 향상시키는 것도 중요하지만 부 정적 양육태도를 감소시키는 노력이 매우 중요하다. 또한, 공 격성이 포함된 경로의 매개효과가 우울이 포함된 경로보다 큰 것으로 나타났다. 스마트폰 과의존은 스마트폰의 균형적인 사 용 조절능력의 부족 상태를 의미하는데(Ministry of Science and ICT, 2020), 아동은 내재적 문제인 우울보다는 외현적 문제인 공격성으로 인해 조절력이 감소하여 스마트폰에 더욱 의존하 게 될 가능성이 보다 높은 것으로 해석할 수 있다. 이는 우울, 공격성이 모두 아동의 스마트폰 과의존에 영향을 미치는 주요 변수이나, 아동의 우울보다 공격성이 스마트폰 과의존과 더 높
은 관련성이 있음을 보여준다. 따라서 스마트폰 과의존 감소를 위해서는 아동의 우울 뿐만 아니라 공격성 감소를 위한 노력이 매우 중요하다는 것을 시사한다. 따라서 스마트폰 과의존 아 동의 공격성을 타겟으로 한 상담 및 치료 등의 적극적 개입을 통해 스마트폰 과의존 문제를 해결하려는 노력이 필요하다.

본 연구의 함의는 다음과 같다. 첫째, 본 연구는 부모의 스 마트폰 과의존이 양육태도와 아동의 우울 및 공격성을 거쳐 아동의 스마트폰 과의존에 미치는 영향을 검증하여 중요 요인 들 간의 자세한 관계를 파악하였다는 점에서 가장 큰 의의가 있다. 아동의 스마트폰 과의존과 관련된 변인의 단편적 영향 을 분석한 연구는 많이 존재하나 부모의 스마트폰 과의존이라 는 변인이 포함된 변인의 구조적 관계를 검증한 연구는 부족 하였다. 또한, 지금까지의 스마트폰 과의존 관련 연구가 대부 분 유아나 청소년을 대상으로 이루어져 아동의 스마트폰 과의 존에는 여떤 요인들이 작용하는지 밝히려는 시도가 부족하였 다. 본 연구에서는 아동을 대상으로 스마트폰 과의존을 일으 키는 변인들 간의 구조적 관계를 밝힘으로써 아동의 스마트폰 과의존 관련 요인들을 정교하게 이해할 수 있게 되었다.

둘째, 아동의 스마트폰 과의존에 부모 요인이 영향을 미친 다는 사실을 밝힘으로써 아동의 스마트폰 과의존 문제 해결을 위한 단서를 제공하였다. 본 연구는 부모가 통제적인 양육태 도를 보일 때보다 자율성을 지지하는 긍정적 양육태도를 보일 때 스마트폰 과의존을 낮출 수 있다는 것을 보여준다. 따라서 스마트폰 과의존을 예방하기 위해 부모가 아동을 지지하고 격 려하는 가정 풍토를 만들 필요가 있다. 또한, 아동의 스마트폰 과의존 감소를 위해 부모 역할이 중요한 만큼 학교나 상담 기 관 등에서 부모에 대해 개입하려는 노력을 지속적으로 기울일 필요가 있다. 예를 들어, 아동에게 스마트폰 과의존이 나타나 는 경우 부모에게 양육 태도 검사를 실시하여 자신의 양육태 도를 성찰하게 하고, 부정적 양육태도가 높은 부모에 대해 상 담 및 교육을 실시하여 태도 개선을 유도할 수 있다. 또한, 긍 정적 양육태도를 가진 부모라도 자녀가 스마트폰에 과의존하 는 모습을 보인다면 자신에게 스마트폰을 의존하는 모습이 있 는지 성찰하고, 아동과 함께 스마트폰 의존을 줄이고자 하는 노력을 기울일 필요가 있다.

셋째, 아동의 스마트폰 과의존을 해결하기 위해서는 아동의 정서 및 행동에 대한 관심 및 개입이 필요함을 확인하였다. 본 연구 결과에 따르면, 아동은 우울과 공격성을 느낄 때 이를 스 마트폰 의존을 통해 해결하려는 것으로 보인다. 현재 학교에서 아동의 스마트폰 과의존 검사는 이루어지고 있으나 아동의 심 리 상태에 대해 진단하는 경우는 미비하다. 게다가 아동의 정서 
적 문제는 쉽게 드러나지 않아 겉으로는 알아 차리기가 힘들다 (Rubin, Coplan, \& Bowker, 2009). 따라서 스마트폰 과의존으로 파악된 아동들에게 심리 검사를 통해 우울, 공격성을 파악하고 이에 대한 교육 및 상담적 개입을 실시한다면 아동이 스마트폰 과의존으로 이어지는 것을 예방하는데 도움이 될 것이다. 또한, 매개효과 비교 검증에서 공격성을 통한 경로가 우울보다 영향 이 큰 만큼 스마트폰 과의존 아동에 대해 공격성을 감소시킬 수 있는 상담 및 프로그램을 적극적으로 운영할 필요가 있다.

본 연구의 제한점과 후속 연구를 위한 제언은 다음과 같다. 첫째, 본 연구는 부모의 특성이 아동의 스마트폰 과의존에 미 치는 영향을 파악하고자 하였으나, 본 연구에서 사용한 부모 의 스마트폰 과의존 및 부모의 양육태도 문항은 부와 모 중 응 답 가능한 보호자 1 명이 응답한 자료이다. 즉, 부 또는 모의 특 성을 부모의 특성으로 가정하고 연구를 진행하였으나, 실질적 으로는 부와 모 중 한 사람만을 대상으로 한 것이며 대부분 어 머니가 응답하였으므로, 부와 모 전체 특성을 대표하는 데에 한계가 있다. 따라서 추후 연구에서는 어머니와 아버지의 응 답을 모두 수집하여 부모의 스마트폰 과의존과 부모의 양육 태도를 측정한다면 보다 정확하게 변인들 간의 관계를 파악할 수 있을 것이다. 둘째, 본 연구는 연구대상을 초등학교 5학년 학생으로 한정하고 있으므로 추후 종단적인 연구를 통해 변인 들 간의 관계를 추적하는 연구가 필요하다. 즉, 아동의 성장에 따라 스마트폰 과의존에 영향을 주는 변인들 간의 관계가 어 떻게 변화하는지 살펴본다면 큰 의의가 있을 것이다. 마지막 으로, 본 연구에서는 부모 요인에 초점을 두어 가정 외의 사회 적 관계가 아동의 스마트폰 과의존에 미치는 영향을 살펴보지 는 못하였다. 후속 연구에서 또래 관계 등이 아동의 스마트폰 과의존에 미치는 경로를 탐색한다면 아동의 스마트폰 과의존 에 대한 확장적인 논의가 가능할 것이다.

\section{Conflict of Interest}

No potential conflict of interest relevant to this article was reported.

\section{References}

\section{In English}

Anwar, S., Saeed, R., Danish, S. H., Azhar, F. (2021). Impact of smartphones on physical and psychosocial well-being of children and adolescent. Asian Journal of Advanced Research and Reports, 15(4), 6-14. doi:10.9734/ajarr/2021/v15i430386

Bandalos, D. L. (2002). The effects of item parceling on goodnessof-fit and parameter estimate bias in structural equation modeling. Structural equation modeling, 9(1), 78-102. doi:10.1207/S15328007SEM0901_5

Beck, A. T., \& Alford, B. A. (2009). Depression: Causes and treatment. Philadelphia, PA: University of Pennsylvania Press.

Browne, M. W., \& Cudeck, R. (1992). Alternative ways of assessing model fit. Sociological methods \& research, 21(2), 230-258. doi:10.1177/0049124192021002005

Bukhori, B., Said, H., Wijaya, T., \& Nor, F. M. (2019). The effect of smartphone addiction, achievement motivation, and textbook reading intensity on students' academic achievement. International Journal of Interactive Mobile Technologies, 13(9), 66-80. doi:10.3991/ijim.v13i09.9566

Chang, F. C., Chiu, C. H., Chen, P. H., Chiang, J. T., Miao, N. F., Chuang, H. Y., \& Liu, S. (2019). Children's use of mobile devices, smartphone addiction and parental mediation in Taiwan. Computers in Human Behavior, 93, 25-32. doi:10.1016/j.chb.2018.11.048

Chen, F. F. (2007). Sensitivity of goodness of fit indexes to lack of measurement invariance. Structural equation modeling: a multidisciplinary journal, 14(3), 464-504. doi:10.1080 /10705510701301834

Chen, F. R., \& Raine, A. (2018). Effects of harsh parenting and positive parenting practices on youth aggressive behavior: The moderating role of early pubertal timing. Aggressive behavior, 44(1), 18-28. doi:10.1002/ab.21720

Collier, J. E. (2020). Applied structural equation modeling using AMOS: Basic to advanced techniques. New York: Routledge.

Cook, W. L., \& Kenny, D. A. (2005). The actor-partner interdependence model: A model of bidirectional effects in developmental studies. International Journal of Behavioral Development, 29(2), 101-109. doi:10.1080/ 01650250444000405

Crick, N. R., \& Grotpeter, J. K. (1995). Relational aggression, gender, and social-psychological adjustment. Child development, 66(3), 710-722. doi:10.1111/j.14678624.1995.tb00900.x

Curran, P. J., West, S. G., \& Finch, J. F. (1996). The robustness of test statistics to nonnormality and specification error in confirmatory factor analysis. Psychological methods, 1(1), 16-29. doi:10.1037/1082-989x.1.1.16

Dallaire, D. H., Pineda, A. Q., Cole, D. A., Ciesla, J. A., Jacquez, F., LaGrange, B., \& Bruce, A. E. (2006). Relation of positive and negative parenting to children's depressive symptoms. Journal of Clinical Child Adolescent Psychology, 35(2), 313322. doi:10.1207/s15374424jccp3502_15 
Flores, P. J. (2004). Addiction as an attachment disorder. Chicago, IL: Jason Aronson.

Hong, S., Malik, M. L., \& Lee, M. K. (2003). Testing configural, metric, scalar, and latent mean invariance across genders in sociotropy and autonomy using a non-Western sample. Educational and psychological measurement, 63(4), 636-654. doi: $10.1177 / 0013164403251332$

Kawabata, Y., Alink, L. R., Tseng, W. L., Van Ijzendoorn, M. H., \& Crick, N. R. (2011). Maternal and paternal parenting styles associated with relational aggression in children and adolescents: A conceptual analysis and meta-analytic review. Developmental review, 31(4), 240-278. doi:10.1016/ j.dr.2011.08.001

Kenny, D. A., Kashy, D. A., \& Cook, W. (2006). Dyadic data analysis. New York: Guilford Press.

Little, T. D., Cunningham, W. A., Shahar, G., \& Widaman, K. F. (2002). To parcel or not to parcel: Exploring the question, weighing the merits. Structural Equation Modeling: A Multidisciplinary Journal, 9(2), 151-173. doi: 10.1207/ S15328007SEM0902_1

Park, C., \& Park, Y. R. (2014). The conceptual model on smart phone addiction among early childhood. International Journal of Social Science and Humanity, 4(2), 147. doi:10.7763/IJSSH.2014.V4.336

Rubin, K. H., Coplan, R, J., \& Bowker, J. C. (2009) Social withdrawal in childhood. Annual review of psychology. 60, 141-171. doi:10.1146/annurev.psych.60.110707.163642

Russell, D. W., Kahn, J. H., Spoth, R., \& Altmaier, E. M. (1998). Analyzing data from experimental studies: A latent variable structural equation modeling approach. Journal of counseling psychology, 45(1), 18-29. doi:10.1037/00220167.45.1.18

Shrout, P. E., \& Bolger, N. (2002). Mediation in experimental and nonexperimental studies: New procedures and recommendations. Psychological methods, 7(4), 422-445. doi:10.1037/1082-989X.7.4.422

Shyan, T. P., \& Arshat, Z. (2019). Parental attachment, smartphone addiction and stress among undergraduate students. Journal of Education, Psychology and Counseling, 4(32), 149-163. doi:10.35631/IJEPC.4320015

Son, H. G., Cho, H. J., \& Jeong, K. H. (2021). The effects of korean parents' smartphone addiction on korean children's smartphone addiction: moderating effects of children's gender and age. International Journal of Environmental Research and Public Health, 18(13), 6685. doi:10.3390/ ijerph18136685

Taylor, K., \& Silver, L. (2019). Smartphone ownership is growing rapidly around the world, but not always equally. Washington DC, WA: Pew research center.

\section{In Korean}

Aum, N. (2018). Smartphone gwauijon siltaewa jeongchaekjeok yebang.haeso noryeok [스마트폰 과의존 실태와 정책적 예 방.해소 노력]. KISO Journal, 30, 32-36.

Boo, E. S., \& Park, J. H. (2018). Mediating effect of mother's original family experience in relation to mother's addiction tendency of smartphone and Children's social competence. Journal of the Korea Academia-Industrial cooperation Society, 19(8), 474-481. doi:10.5762/KAIS.2018.19.8.474

Chang, Y. O. (2015a). The effects of parental behaviors on adolescent overt aggression and depression. Korean Journal of Youth Studies, 22(2), 199-221.

Chang, Y. O. (2015b). The effects of mothers' smartphone addiction on parenting efficacy and parenting attitude. Korean Journal of Childcare and Education, 11(2), 109-129. doi:10.14698/JKCCE.2015.11.2.109

Cho, S. H., \& Cho, A. N. (2021). The relationship between parents' smartphone dependence and adolescent's smartphone dependence: The mediating effects of negative parenting attitude and adolescent's depression. Journal of Learner-Centered Curriculum and Instruction, 21(14), 369379.

Cho, Y., \& Lee, H. (2016). The effects of mothers' smart phone addiction tendency on smart phone addiction tendency in young children with the mediating effects of young children's self-regulation. Korean Journal of Child Psychotherapy, 11(2), 1-16.

Choi, D. H. (2019). A study on relationship between mother's smartphone overdependence, parental role intelligence. Journal of The Korea Society of Computer and Information, 24(1), 225-230. doi:10.9708/jksci.2019.24.01.225

Choi, H. S., Lee, H. K., \& Ha, J. C. (2012). The influence of smartphone addiction on mental health, campus life and personal relations-focusing on $\mathrm{K}$ university students. Journal of the Korean Data and Information Science Society, 23(5), 1005-1015. doi:10.7465/jkdi.2012.23.5.1005

Choi, I. (2012). Effects of maternal parenting behavior on early adolescents' depression according to sex: Moderating effects of social support and negative emotional experience. Korean journal of youth studies, 19(1), 135-160.

Choi, J., \& Kwon, H. J. (2016). The effects of inconsistent parenting attitude on smart phone addiction of adolescents. Korean Journal of Health Education and Promotion, 33(2), 39-45. doi:10.14367/kjhep.2016.33.2.39

Choi, T. S., \& Kim, J. K. (2015). The influence of school adjustment and perceived parental attitude on the depression of school-aged children: The moderating effects of perceived parental attitude. Korean Journal of Youth 
Studies, 22(12), 595-617.

Ha, M. S. (2020). Relationship between mother's smartphone addiction and adolescents' smartphone addiction: verification of multiple mediating effects of negative parenting attitude, social withdrawal, and depression. Asian Journal of Education, 21(4), 1001-1035.

Hong, S. H. (2000). The criteria for selecting appropriate fit indices in structural equation modeling and their rationales. Korean Journal of Clinical Psychology, 19(1), 161-177.

Hong, S. H., \& Jung, S. (2014). Testing the interaction effects in regression and structural equation models: theories and procedures. The Korean Journal of the Human Development, 21(4), 1-24. doi:10.18211/kjhrdq.2019.21.4.001

Jeong, J. S., \& Lee, H. K. (2020). A study on factors affecting smartphone addiction in children and adolescents: Focusing on the comparison between 4th-grade elementary school students and 1st-grade middle school students. Journal of Youth Wellfare, 22(4), 211-241.

Jo, B. H. \& Im, G. H. (2003). Development and validation of emotional or behavioral problems scale. The Korean Journal of Counseling and Psychotherapy, 15(4), 729-746.

Joo, J. (2013). Exploring relationships among korean children's depression, smartphone addiction, and school life satisfaction: Focusing on Partial Least Square (PLS) path modeling. Journal of digital convergence, 11(12), 49-60. doi:10.14400/JDPM.2013.11.12.49

Kang, B. G., \& Shin, H. J. (2014). Risk and protective factors affecting mobile phone addiction in adolescence: With a special focus on the comparison by gender. Korean Journal of Youth Studies, 21(8), 213-241.

Kim, D. I., Chung, Y. J., Lee, J. Y., Kim, M. C., Lee, Y. H., Kang, E. B., Keum, C. M., \& Nam. J. E. (2012). Development of smartphone addiction proneness scale for adults: Selfreport. Korea Journal of Counseling, 13(2), 629-644. doi:10.15703/kjc.13.2.201204.629

Kim, J. H. (2013). Influence of depression and aggression of adolescents on cyber and real-world delinquency mediated by types of internet use. Journal of School Social Work, 24, 31-59.

Kim, J. H., \& Ahn, G. Y. R. (2013). The effects of parents' rearing attitudes as perceived by middle school students for school adjustment: Self-regulation as a mediating variable. Korean Journal of Health Psychology, 18(4), 823-836. doi:10.17315/ KJHP.2013.18.4.013

Kim, J. K, \& Lee, D. H. (2018). The influence of adolescents' aggression and social withdrawal upon smart-phone overdependence: Focusing on a moderated mediation effect of self-esteem. Journal of Welfare for the Correction, 57, 1-30.

Kim, K. I., Kim, J. H., \& Won, H. T. (1984). Gani jeongsinjindangeomsa silsiyogang [간이 정신진단검사 실시
요강]. Seoul: Jungangjeokseong culpansa.

Kim, N. R., Kim, J. M., \& Jeon, J. E. (2019). The effects of mothers' smartphone overdependence on children's problem behaviors: The dual mediating effects of children's effortful control and smartphone overdependence. Korean Journal of Child Studies, 40(4), 95-107. doi:10.5723/ kjcs.2019.40.4.95

Kim, S. Y., \& Hong, S. H. (2014). Estimating adolescent's changes in mobile phone dependence: Testing for the effects of ecological factors on individual differences in the changes. Studies on Korean Youth, 25(3), 101-123. doi:10.14816/ sky.2014.25.3.101

Kim, S. Y., Kim, J. H., \& Lee, G. Y. (2004). The relationships of parenting behavior perceived adolescents, aggression, selfcontrol and self-esteem and delinquency of adolescents. The Korea Journal of Couneling, 5(3), 711-723.

Kim, T. M., \& Lee, E. J. (2017). Validation of the korean version of parents as social context questionnaire for adolescents: PSCQ_KA. Korean Journal of Youth Studies, 24, 313-333.

Kim, Y. H. (2019). Eoriniwa cheongsonyeonui hyudaepon boyu mit iyonghaengtae bunseok [어린이와 청소년의 휴대폰 보유 및 이용행태 분석]. KISDI STAT Report, 18(20), 1-7.

Kim, Y. M., \& Kim, D. B. (2016). Mediating effects of self-control on the relationship between smartphone use and school adjustment in middle school students. Korean Journal of Youth Studies, 23(3), 133-162.

Ku. H. J. (2013). Effects of the parents' rearing attitude, perceived by middle school students, on depression: mediating effects of the unconditional self-acceptance. Korean Journal of Youth Studies, 20(12), 295-315.

Lee, D. Y., Jung, G. H., \& Seo, H. Y. (2017). Suicidal ideation, social support and self-esteem in middle school students according to the degree of depression. Journal of the Korean Society of School Health, 30(2), 136-145. doi:10.15434/ kssh.2017.30.2.136

Lee, H. N., \& Yang, S. M. (2018). Differential effects of parenting styles, psychological traits, and purpose of smartphone use upon Korean adolescents' smartphone dependence. Korean Journal of Journalism Communication Studies, 62(5), 175214.

Lee, J. Y., \& Jang, S. Y. (2014). The intermediary effect of egoresilience in the relationship between a mother's parenting behaviors and smartphone addiction. Korean Journal of Child Education and Care, 14(3), 61-79.

Lim G. O. (2017). Parenting styles on depression and aggression in adolescents. Family and Family Therapy, 25(2), 251-274.

Ministry of Science and ICT (2020). 2020 The survey on smartphone overdependence. Sejong: Ministry of Science and ICT

Moon, D. S., \& Choi, E. (2015). The effect of parental rearing attitudes on smart phone addiction of adolescents: the 
mediating effect of self-esteem. Korean Journal of youth studies, 22(10), 213-236.

Moon, H. J., \& Shin, H. K. (2020). The effects of aggression and depression of smartphone addiction in university students: Focusing on the moderating effects of self-control. The Journal of Humanities and Social Sciences 21, 11(1), 861872.

Nho, C. R., \& Kim, S. Y. (2016). The effects of parenting attitudes on adolescents' smartphone dependency: The mediating effects of adolescents' depression and aggression. Studies on Korean Youth, 27(4), 87-114. doi:10.14816/ sky.2016.27.4.87

Oh, C. M., \& Kong, I. S. (2007). The effect of children's perceived parenting behaviors on their aggression. Journal of Korean Home Management Association, 25(4), 139-150.

Park, H., Jang, E., Yoo, M., \& Koo, H. (2005). The relation among smoking behaviors, self-esteem, hostility, and depression for adolescents. The Korean Journal of Counseling, 6(4), 13211333.

Park, J., \& Hyun, E. J. (2018). Analysis on the structural relationships of young children's smartphone overdependence, young children's aggression, mothers' parenting stress, and mothers' smartphone addiction tendency. Journal of Children's Literature and Education, 19(2), 219-248.

Park, K. H., \& Park, E. M. (2020). Mediating effect of self-efficacy between aggressiveness and smartphone addiction in adolescents. The Journal of the Korea Contents Association, 20(7), 516-524. doi:10.5392/JKCA.2020.20.07.516
Ryu, K. H., \& Hong, H. Y. (2014). The relationship between overt, covert narcissism and smart phone addiction of middle school students: The mediating effects of aggression. Korean journal of youth studies, 21(8), 157-183.

Yim, H. R., Kim, S. H., \& Chung, I. J. (2014). The differential effects of positive parenting attitudes on adolescents' psychosocial adjustment. Journal of Adolescent Welfare, 16(4), 1-27.

You, H. J. (2014). The structural relationship among experience of abuse for early adolescent, depression, aggression, social withdrawal, and mobile phone dependency: Focusing on gender differences. Korean Journal of Youth Studies, 21(12), 417-446.

\section{ORCID}

Sojin Yoon

Myeongseong Lee Joonwoo Lee

Sehee Hong http://orcid.org/0000-0002-3034-1469

http://orcid.org/0000-0002-9323-3289

http://orcid.org/0000-0002-5053-9325

http://orcid.org/0000-0001-5468-8398
Received August 30, 2021 Revision received October 22, 2021 Accepted December 2, 2021 